J. Dairy Sci. 95:5115-5126

http://dx.doi.org/10.3168/jds.2011-4833

(C) American Dairy Science Association ${ }^{\circledR}, 2012$.

\title{
The effects of hybrid, maturity, and length of storage on the composition and nutritive value of corn silage
}

\author{
M. C. Der Bedrosian, ${ }^{\star}$ K. E. Nestor Jr., $†$ and L. Kung Jr. ${ }^{* 1}$ \\ *University of Delaware, Newark 19716 \\ †Mycogen Seeds, Indianapolis, IN 46268
}

\begin{abstract}
The objective of this study was to evaluate the effect of hybrid, maturity at harvest [dry matter (DM) content], and length of storage on the composition and nutritive value of corn silage. The plants used in this study included a normal (NORM) and a brown midrib (BMR) hybrid, harvested at 32 or $41 \% \mathrm{DM}$ and ensiled for various lengths of time (0 to $360 \mathrm{~d})$ without inoculation. Measurements included nutrient analysis, fermentation end products, in vitro digestion of NDF (NDF-D, $30 \mathrm{~h})$, and in vitro digestion of starch $(7 \mathrm{~h}$ ). The concentration of acetic acid increased with length of storage for all treatments, specifically increasing as much as $140 \%$ between d 45 to 360 for $32 \%$ DM BMR silage. Small changes in lactic acid and ethanol were noted but varied by DM and hybrid. When averaged across maturities and length of storage, compared with NORM, BMR silage was lower in concentrations of lignin, crude protein, neutral detergent fiber, and acid detergent fiber, but higher in starch. On average, NDF-D of both hybrids was not affected by length of storage between 45 and $270 \mathrm{~d}$. The NDF-D was markedly greater for BMR than NORM after all times of storage. Increasing maturity at harvest generally did not affect the NDF-D of NORM, with the exception that it was slightly lower for the more mature plants at 270 and $360 \mathrm{~d}$. In contrast, the NDF-D of BMR was lower in more mature silage by approximately 5 percentage units from 45 to $360 \mathrm{~d}$. The concentration of starch for $32 \%$ DM NORM was lower (21\%) than other treatments $(31 \pm 3 \%$; mean $\pm \mathrm{SD})$ at harvest. This finding was probably the cause for starch digestibility to be highest in $32 \%$ DM NORM samples at d 0 (about $80 \%$ ) and lower (65 to 68\%) for other treatments. Concentrations of soluble $\mathrm{N}$ and ammonia- $\mathrm{N}$ increased with length of storage, indicating that proteolytic mechanisms were active beyond 2 to 3 mo of storage. The in
\end{abstract}

Received August 12, 2011

Accepted April 24, 2012.

${ }^{1}$ Corresponding author: lksilage@udel.edu vitro digestion of starch generally increased with length of storage, probably as a result of proteolysis. Although active fermentation occurs for only a relatively short time in the silo, many metabolic processes remain active during long-term storage. Changes in the nutritive value of corn silage during storage should be accounted for during ration formulations.

Key words: silage, brown midrib, digestibility

\section{INTRODUCTION}

During the active stage of ensiling, epiphytic lactic acid bacteria ferment water-soluble sugars primarily to lactic acid, which causes a decrease in the $\mathrm{pH}$ of the forage mass. It has been generally accepted that most active metabolic processes in the silo cease after about 2 to 6 wk of ensiling (depending on various conditions), as long as air is prevented from penetrating the mass during storage, resulting in a stable phase of ensiling (Pahlow et al., 2003). However, some microbial processes have been shown to occur during prolonged storage. For example, Kleinschmit and Kung (2006) reported that Lactobacillus buchneri remained fairly active for prolonged periods of time (up to a year) in silage, even under anaerobic conditions at a low $\mathrm{pH}$. Evidence for this was supported by the fact that 1,2-propanediol, a product of metabolism of lactic to acetic acid by this organism, continually increased with time of storage. Other processes also appear to continue after active fermentation appears complete. For example, Kleinschmit and Kung (2006) reported that ammonia-N was twice as high in untreated corn silage after $361 \mathrm{~d}$ compared with $282 \mathrm{~d}$ of ensiling. Accumulation of ammonia-N is thought to be primarily of microbial origin (Ohshima and McDonald, 1978).

Although not directly fermented by lactic acid bacteria, the fibrous fraction of silages also appears to change with time of storage. Morrison (1979) reported that acid hydrolysis results in some degradation of hemicellulose during ensiling. Hallada et al. (2008) reported that NDF digestibility of corn silage increased substantially with advancing time of storage. Benton et al. (2005) reported a constant increase in in situ 
DM digestibility of high-moisture corn (HMC) with prolonged length of storage, but did not elaborate on specific reasons for this finding. In corn silages, Newbold et al. (2006) reported that in vitro starch digestion and soluble $\mathrm{N}$ contents of corn silage also increased with longer times of storage in the silo. Although some have suggested that improvements in starch digestion may have been due to chemical solubilization, recent evidence from Hoffman et al. (2011) suggested that proteolytic activity was responsible for the degradation of hydrophobic zein proteins in HMC over extended periods of ensiling. Collectively, these data suggest that several important metabolic processes continue in what has been considered the stable phase of ensiling.

The objective of this study was to further investigate the effect of prolonged length of storage (i.e., up to $360 \mathrm{~d}$ ) on the fermentation end products and nutritive value of a normal and a brown midrib silage hybrid harvested at 2 stages of maturity. To our best knowledge, we are the first to evaluate these specific variables in the same study.

\section{MATERIALS AND METHODS}

The corn used in this experiment was taken from fields that were planted to feed cows at the University of Delaware (Newark). Corn was planted in fields of silt loam soil. The fields had been managed with a cornalfalfa rotation, every $4 \mathrm{yr}$. In the last year of the alfalfa rotation, following the last alfalfa harvest, no-till planting of corn was done using Round-Up (Monsanto Co., St. Louis, MO) or Gramoxone (Syngenta Crop Protection Inc., Greensboro, NC). The fields were fertilized with manure (sheep, beef, and horse), followed by a field finisher, applied with a rolling basket and tines. After this, a dry fertilizer starter (10-20-20, N-P-K; Milford Fertilizer, Milford, DE) was applied at a rate of $112 \mathrm{~kg} / \mathrm{ha}$, as was Broad Strike-Dual herbicide (Dow AgroSciences LLC, Indianapolis, IN) and a 30\% urea ammonium nitrate solution (UAN; CF Industries Inc., Long Grove, IL). Corn was planted at a theoretical density of 72,500 seeds/ha in $0.76-\mathrm{m}$ rows.

A normal corn hybrid (NORM; 33A88; Pioneer HiBred International Inc., Des Moines, IA) and a brown midrib hybrid (BMR; F2F723; Mycogen Seeds, Indianapolis, IN) were used in this study. Plants were harvested at 2 maturities ( 32 and $41 \% \mathrm{DM}$ ) and ensiled for $0,45,90,180,270$, and $360 \mathrm{~d}$. Forage from 5 individual rows of plants (approximately $20 \mathrm{~m}$ in length) from random locations in the fields was harvested for each hybrid, at both DM. Forage was chopped to a theoretical length of $19 \mathrm{~mm}$ using a New Holland FP230 (New Holland, PA) pull-type harvester equipped with a mechanical processor. About $500 \mathrm{~g}$ of chopped forage from each row was packed in nylon-polyethylene standard barrier micro-layered pouches (3.5-mil thickness, $15.2 \times 30.5 \mathrm{~cm}$; Doug Care Equipment Inc., Springville, CA), vacuumed, and heat sealed with a Best Vac vacuum machine (distributed by Doug Care Equipment Inc., Springville, CA). Bags had a layer of polyethylene mesh sealed into the entire length of the pouch, which assisted in the removal of air during the vacuum process. A sufficient number of silos were prepared such that 5 silos were opened for each hybrid and DM at the 5 times of ensiling. Silos were stored in the laboratory between 22 and $23^{\circ} \mathrm{C}$ until opening. Chopped samples of fresh forages from each row for each treatment served as replicate samples for $\mathrm{d} 0$.

Representative samples of fresh forages and silages (25 g) were combined with $225 \mathrm{~mL}$ of sterile Ringer's solution (Oxoid BR0052G; Oxoid Ltd., Cambridge, UK) and homogenized for 1 min on a medium setting in a Proctor-Silex 57171 blender (Hamilton Beach / Proctor-Silex Inc., Washington, NC). A portion of the homogenate was filtered through Whatman 54 filter paper (Whatman Ltd., Florham, NJ) and acidified with 3 drops of $50 \% \mathrm{H}_{2} \mathrm{SO}_{4}$ to reduce the $\mathrm{pH}$ of the extract to $<2.0$, and the water extract was frozen $\left(-20^{\circ} \mathrm{C}\right)$ until further analysis. Water extracts were analyzed for ammonia- $\mathrm{N}\left(\mathrm{NH}_{3}-\mathrm{N}\right)$ according to the colorimetric method described by Weatherburn (1967).

Fresh forage and silages were analyzed for DM content by drying samples in a forced-air oven at $60^{\circ} \mathrm{C}$ for $48 \mathrm{~h}$. A portion of each dried sample was ground through a 1-mm screen using a Udy Cyclone Sample Mill (Udy Corp., Fort Collins, CO) and it was used for the analysis of fiber residues. Neutral detergent fiber was quantified through use of the procedures of Van Soest, et al. (1991), using amylase and sodium sulfite. Acid detergent fiber was quantified in ground samples according to procedures described by Goering and Van Soest (1970), with the modification that the fiber residue from the ADF was recovered on a 1.5- $\mu \mathrm{m}$ particle retention 7 -cm Whatman glass fiber filter in a California Buchner Funnel instead of a Gooch crucible, to allow for better filtration. Analysis of NDF and ADF was not sequential, and quantities of NDF and ADF are on a DM (not on reported ash-free) basis. After ADF determination, the filter residue and filter were transferred to a glass tube, where $45 \mathrm{~mL}$ of $72 \% \mathrm{H}_{2} \mathrm{SO}_{4}$ was added. Tubes were agitated for $2 \mathrm{~h}$, at which point the fiber material was washed with acid continuously. The contents of the tube after the acid incubation were filtered onto a glass fiber filter, rinsed, and weighed. Filters and residue were then ashed for $2 \mathrm{~h}$ in a muffle furnace at $500^{\circ} \mathrm{C}$ to remove the $\mathrm{OM}$ and then weighed back and subtracted from the original sample weight for quantification of lignin residues. 
Table 1. Statistical analysis ( $P$-values) of the influence of hybrid $(\mathrm{H}), \mathrm{DM}$ at harvest $(\mathrm{DM})$, and length of storage $(\mathrm{T})$ on the nutritive value (DM basis, unless stated otherwise) of corn silage

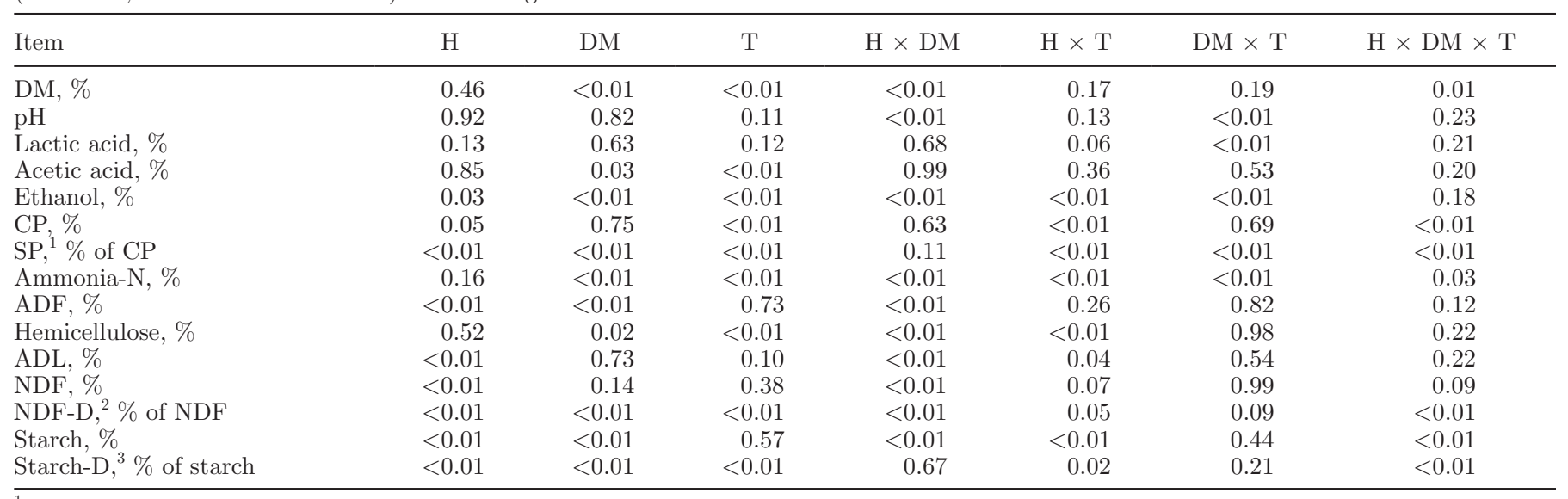

${ }^{1}$ Soluble protein.

${ }^{2}$ In vitro NDF digestibility, $30 \mathrm{~h}$.

${ }^{3}$ In vitro starch digestibility, $7 \mathrm{~h}$.

In vitro 30-h digestibility of NDF (NDF-D; 2-mm screen, Udy Cyclone mill; Udy Corp.) was determined according to the methodology described by Tilley and Terry (1963). Total N was determined by combustion of the sample (Leco CNS 2000 Analyzer; Leco Corp., St. Joseph, MI) and CP was calculated by multiplying the resulting total $\mathrm{N}$ by 6.25 . The starch content of each sample was determined and corrected for free glucose according to the methodology described by Hall (2009). A 7-h in vitro starch digestibility (starch-D) was performed (Tilley and Terry, 1963) on samples ground through a Wiley Mill (Thomas Scientific, Swedesboro, NJ) to pass through a $3-\mathrm{mm}$ screen. The amount of soluble protein (SP) was also determined on these 3 -mm ground samples according to methodology described by Krishnamoorthy et al. (1982).

The data were analyzed as a $2 \times 2 \times 6$ factorial arrangement of treatments with factors including 2 hybrids (NORM and BMR), 2 stages of maturity (low $\mathrm{DM}$ and high $\mathrm{DM})$ and the 6 lengths of storage $(0$, $45,90,180,270$, and 360 d). Data were analyzed with the ANOVA method of the least squares fit model procedure of JMP (SAS Institute Inc., Cary, NC) and differences were reported as significant when $P<0.05$.

\section{RESULTS AND DISCUSSION}

The statistical analysis of the data set is in Table 1. Because an argument could be made that the replicated plots were not truly replicated fields, the majority of our discussion will be based effects on time of storage on the 2 corn silage varieties and not centered on differences between hybrids. Multiple interactions between and among the main effects were also observed in this study. Because of this, the data are presented in graphic form and discussions are limited to those items that were deemed as having major importance.

The $\mathrm{DM}$ and $\mathrm{pH}$ of forages and silages are presented in Figure 1. As expected, the DM content of silages was greater for more mature corn silage but it was not affected by type of hybrid. Dry matter content of silage was affected by length of storage, with a general tendency for DM content to increase with longer storage, similar to the results of Yan et al. (2009). The $\mathrm{pH}$ of fresh forage ranged from 5.77 to 5.83 and decreased to an average of 3.72 after $45 \mathrm{~d}$ of ensiling, which is similar to corn silage harvested from our farm over the several past studies (Kleinschmit and Kung, 2006; Hu et al., 2009; Schmidt and Kung, 2010). The pH of silages remained fairly consistent in $32 \%$ DM silages, but it decreased after $180 \mathrm{~d}$ of ensiling for $41 \%$ DM silage. However, although statistically significant, the actual difference was very small.

Although the literature references a stable phase of the ensiling process (Pahlow et al., 2003), previous studies have shown that certain chemical components and indices of nutritive value in silages continue to change even after the active stage of ensiling has ended. For example, prolonged storage has sometimes resulted in silages with lower concentrations of lactic acid, but higher acetic acid when compared with the same silage that had ensiled for only a few months (Kleinschmit and Kung, 2006; Herrmann et al., 2011). The reason for these findings is due to the fact that some strains of lactic acid bacteria are able to utilize lactic acid anaerobically when glucose is limiting (Lindgren et al., 1990). Furthermore, we now know that $L b$. buchneri is metabolically active in silage for months even in silage with 

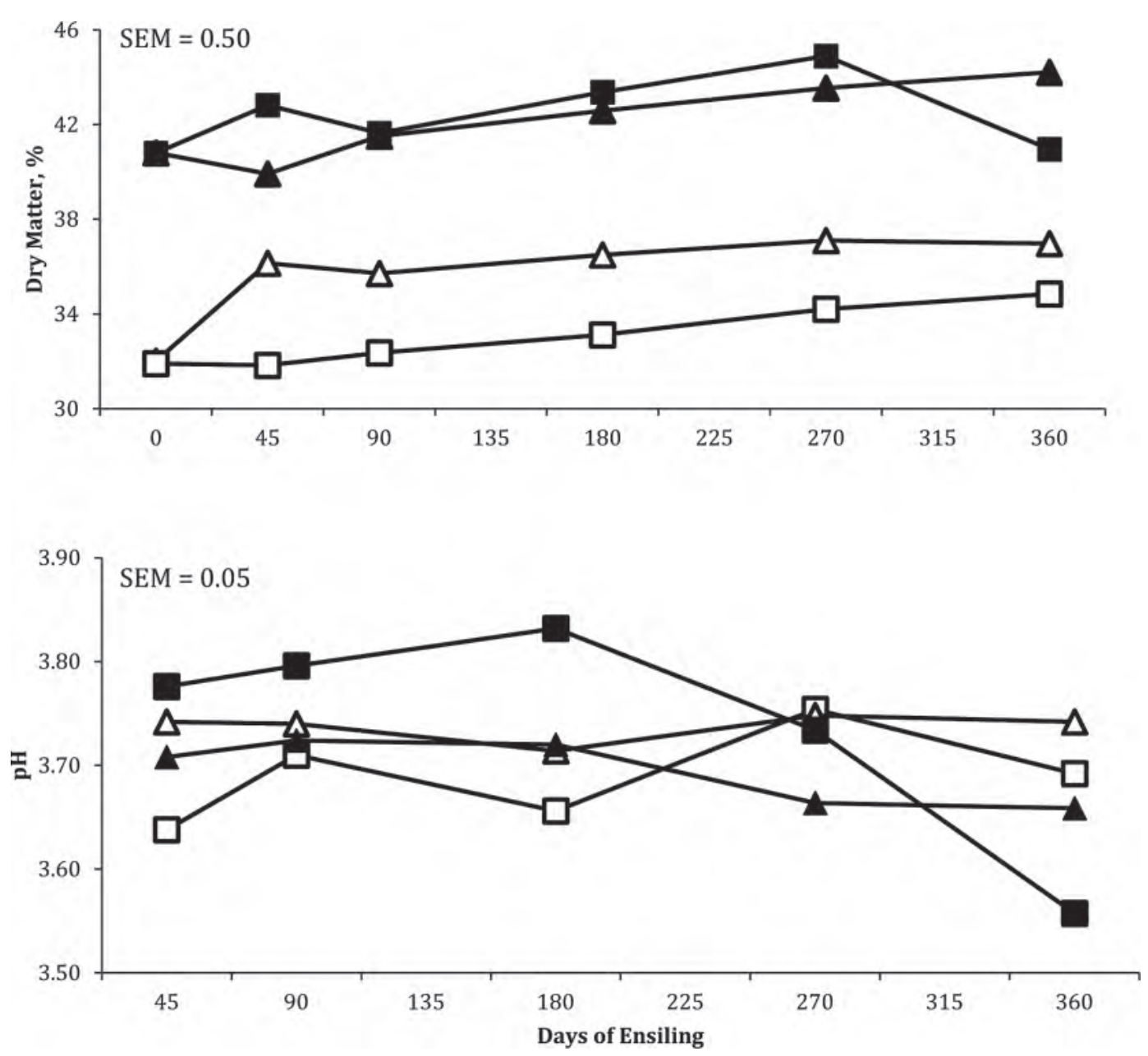

Figure 1. The DM and $\mathrm{pH}$ of forages. $\square=32 \%$ DM normal hybrid; $\Delta=32 \%$ DM brown midrib hybrid; $\mathbf{\square}=41 \%$ DM normal hybrid; $\boldsymbol{\Delta}$ $=41 \%$ DM brown midrib hybrid.

a low pH (Kleinschmit and Kung, 2006). In contrast, other studies have reported that lactic acid increases with prolonged storage (Grum et al., 1991), but this still emphasizes the fact that lactic acid bacteria are quite acid tolerant and are active for prolonged periods in the silo. In the current study, the only significant effect on the concentration of lactic acid was a DM $\times$ length of storage interaction as it increased with time between 45 and $360 \mathrm{~d}$ for high $41 \%$ but not $32 \%$ DM silages (Figure 2). No other main effects or interactions among treatments were observed on the concentration of lactic acid. In contrast, the concentration of acetic acid increased steadily with length of storage from $0.98 \%$ at $\mathrm{d} 45$ to $1.71 \%$ at $\mathrm{d} 360$ and was also higher (1.42\%) in 32\% DM silage than 41\% DM (1.16\%) silage (Figure 2). Lower concentrations of acetic acid (a good antifungal agent) in high-DM corn silage maybe one contributing factor that explains why such silages tend to be less aerobically stable than silages that have high moisture contents. Type of hybrid did not affect the concentration of acetic acid, nor were any interactions observed among the treatments in the current study. Overall, the concentration of ethanol increased with length of storage (Figure 2) but interactions existed between hybrid $\times$ length of storage and DM $\times$ length of storage. The concentration of ethanol was higher in NORM than BMR and was higher in $41 \%$ DM than in $32 \%$ DM silages, but interactions existed between hybrid $\times$ DM. In $32 \%$ DM silages, the concentration of ethanol increased from d 45 to 90 but remained constant thereafter. In contrast, the concentration of ethanol increased steadily with length of storage in 41\% DM NORM silages. The 41\% DM NORM silage had the highest concentration of ethanol (almost twice that of the other treatments), which might have been caused by a high population of yeasts due to the low concentration of acetic acid, but this is only speculation as we did not analyze for microbial populations in this 

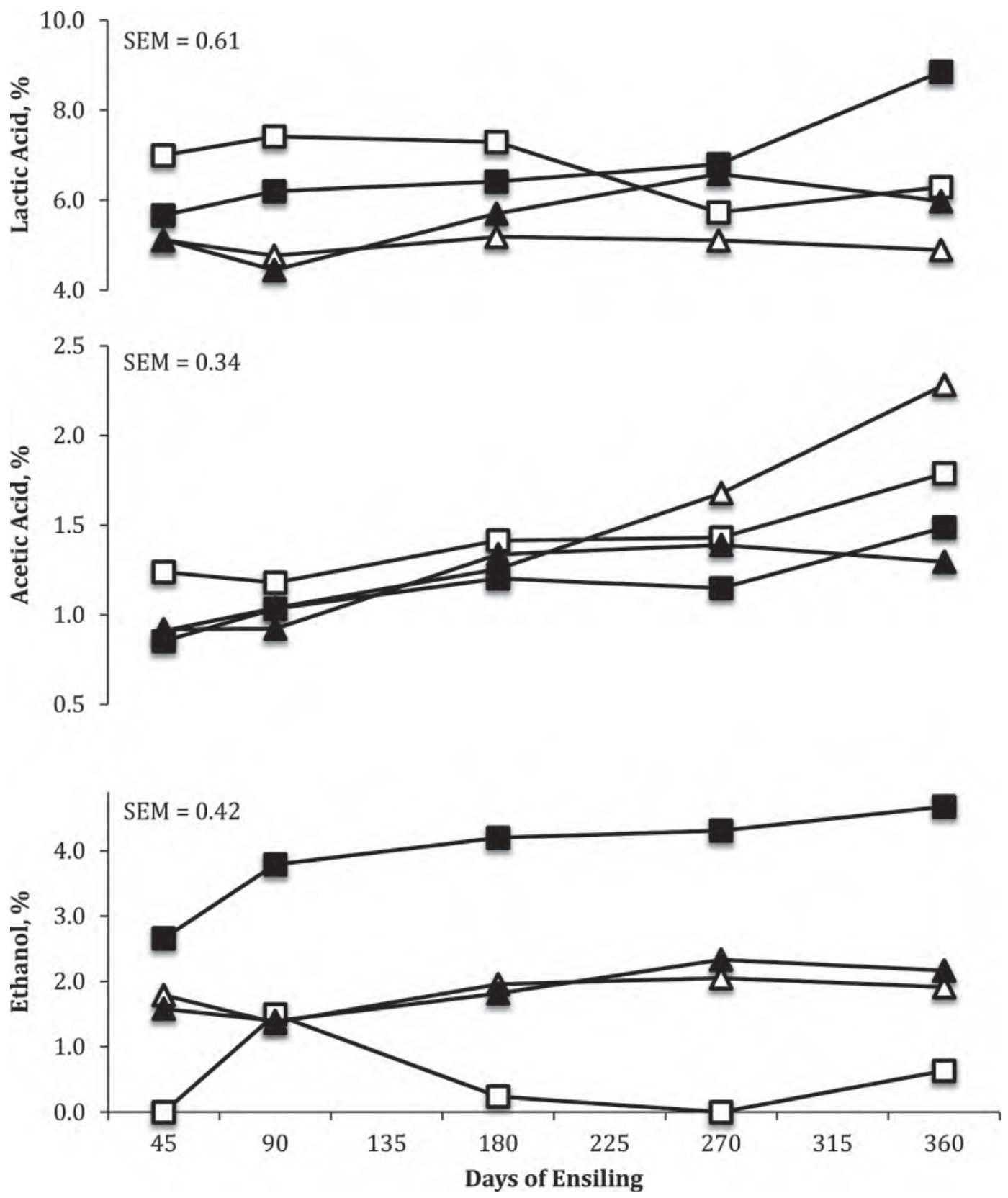

Figure 2. The concentrations (\% DM basis) of lactic acid, acetic acid, and ethanol in silages. ( $\square=32 \%$ DM normal hybrid; $\Delta=32 \%$ DM brown midrib hybrid; $\boldsymbol{\square}=41 \% \mathrm{DM}$ normal hybrid; $\boldsymbol{\Delta}=41 \% \mathrm{DM}$ brown midrib hybrid).

study. Higher concentrations of ethanol have also been reported (Hu et al., 2009) in corn silage harvested at higher DM (40.6\%) than at lower DM (33.1\%).

The ADF, ADL, NDF, hemicellulose, and NDF-D content of the silages are shown in Figure 3. The concentrations of ADF and NDF of silages were not affected by length of storage and no interactions were found between length of storage and type of hybrid or maturity. Hybrid $\times$ maturity interactions occurred for ADF and NDF because harvesting at $41 \% \mathrm{DM}$, as opposed to
$32 \% \mathrm{DM}$, resulted in a greater quantity of these fractions in BMR silage, but this difference was reversed in NORM silage. Sanderson (1993) also reported that ensiling did not affect the NDF content of corn silage stored for up to $186 \mathrm{~d}$. In contrast, Herrmann et al. (2011) reported that the NDF in corn silage decreased from $42.7 \%$ in fresh forage to $36.9 \%$ in silage stored for 365 d. In our study, hemicellulose remained constant for NORM but decreased in BMR with length of storage possibly because the later contained less lignin. Mor- 
rison (1979) reported a 10 to $20 \%$ loss in hemicellulose in silage during fermentation, presumably due to acid hydrolysis. Generally, the ADL content of silages in our study was lower for BMR (1.67\%) than NORM (3.09\%) and although it remained constant throughout storage for BMR, it was lower in fresh forage (about 2.9\%) than in ensilage (about 3.2\%) for NORM silage. Lack of changes in the concentration of lignin with length of ensiling agrees with previous studies (Morrison, 1979; Herrmann et al., 2011).

The NDF-D in our study was higher in fresh forage when compared with silage (Figure 3). Similar findings have been reported by others (Sanderson, 1993; Cherney et al., 2007) and may be the result of some solubilization of fiber early during ensiling. Between 45 and $360 \mathrm{~d}$ of storage, NDF-D was relatively constant when averaged across hybrids and maturities. Although some small differences were observed among treatments at the later stages of storage, differences were small. Sanderson (1993) also found that NDF-D did not change in corn silage stored between 45 and $186 \mathrm{~d}$, but Hallada et al. (2008) reported that it increased by approximately 1.2 percentage units per month between fresh corn plants and silage stored for 6 mo. The reasons for the differences among studies are unknown but may be attributable to differences in growing seasons, the hybrids evaluated, or techniques used to measure NDF-D (or all of these). As expected, the BMR silage in the current study had higher NDF-D than NORM and is due to the fact that lignin content is inversely correlated to fiber digestibility (Jung and Deetz, 1993). A hybrid $\times$ maturity $\times$ length of storage interaction for NDF-D occurred in our study. In particular, harvesting corn plants at a $41 \%$ DM did not affect in vitro NDF-D for NORM silage but BMR silage harvested at $42 \%$ DM was consistently about 5 percentage units lower in in vitro NDF-D than its $31 \%$ DM counterpart from harvest through $360 \mathrm{~d}$ of storage. Similarly, Lewis et al. (2004) also reported a larger decrease in NDF-D for BMR silage compared with conventional hybrids between a medium and late harvest date for corn silages. The lack of maturity affecting NDF-D for NORM silage in the present study was supported by the findings of $\mathrm{Hu}$ et al. (2009), who also reported that in vitro NDF-D was not different when comparing silages of 32.7 and $39.1 \%$ DM. In contrast, Ferreira and Mertens (2006) reported that in vivo NDF-D was lower in $34 \%$ DM compared with $42 \%$ DM corn silage. Differences in specific hybrids used among the studies may explain these findings. Although hybrid $\times$ maturity and hybrid $\times$ time interactions for ADL were observed, the differences were numerically small (Figure 3 ). Of practical significance, ADL was lower in BMR and NORM and did not change in concentration between the hybrids between 45 and $360 \mathrm{~d}$ of storage.

The concentrations of CP, SP, and ammonia-N are in Figure 4. Three-way interactions were observed for all of these components. Concentrations of SP and ammonia$\mathrm{N}$, products of protein degradation, generally increased with length of storage. Although these increases are undesirable, they are generally unavoidable because proteolysis is primarily a result of plant and microbial proteases, whereas deamination occurs via microbial metabolism (Grum et al., 1991). Although degradation of plant proteins during ensiling is a well-known fact (Bergen et al., 1974), most studies have only measured these components for relative short times of ensiling (usually less than 60-90 d; Grum et al., 1991; Guo et al., 2007). In addition, proteolysis is clearly more extensive in legumes than in grasses (Papadopoulos and McKersie, 1983), and most research in this area has been focused on degradation of ribulose 1,5-bisphosphate carboxylase/oxygenase in alfalfa (Jones et al., 1995). The observations of steady increases in SP and ammonia- $\mathrm{N}$ with increasing length of storage for corn silage in our study were similar to those reported by Hoffman et al. (2011) with HMC ensiled through 240 d. In that study, they specifically showed that concentrations of zein proteins decreased with advancing length of storage. Unabated proteolysis during long-term storage of silages is not surprising because some plant proteases are known to be active at very low $\mathrm{pH}$ (Heron et al., 1986, 1989). In addition, lactic acid bacteria are the dominating population of microbes involved in the fermentation process and are relatively acid tolerant, and they possess a wide variety of extracellular proteases and intracellular peptidases (Kunji et al., 1996).

The concentrations of starch and starch-D are shown in Figure 5. A hybrid $\times$ maturity $\times$ length of storage interaction for the concentration of starch was observed. It remained fairly constant throughout storage for BMR silages, but decreased slightly for NORM silages. In addition, the starch content of $32 \%$ DM NORM was lower than expected $(21.3 \%)$ and was less than that of other silages at harvest (range 28.9 to $34.8 \%$ ). A 3-way interaction for starch-D also occurred. It was higher at harvest for $32 \%$ DM NORM (80\%) when compared with other treatments (range of 66 to $68 \%$ ). As length of storage progressed, starch-D increased in all silages but the degree of increase differed among hybrids and maturity. Starch digestibility was highest at harvest and increased only marginally for 32\% DM NORM between fresh forage and $45 \mathrm{~d}$ of ensiling. In contrast, it remained constant in $41 \%$ DM BMR, but increased by d 90 for $32 \%$ DM BMR and 41\% DM NORM. After $90 \mathrm{~d}$, starch-D increased in all hybrids and DM except 

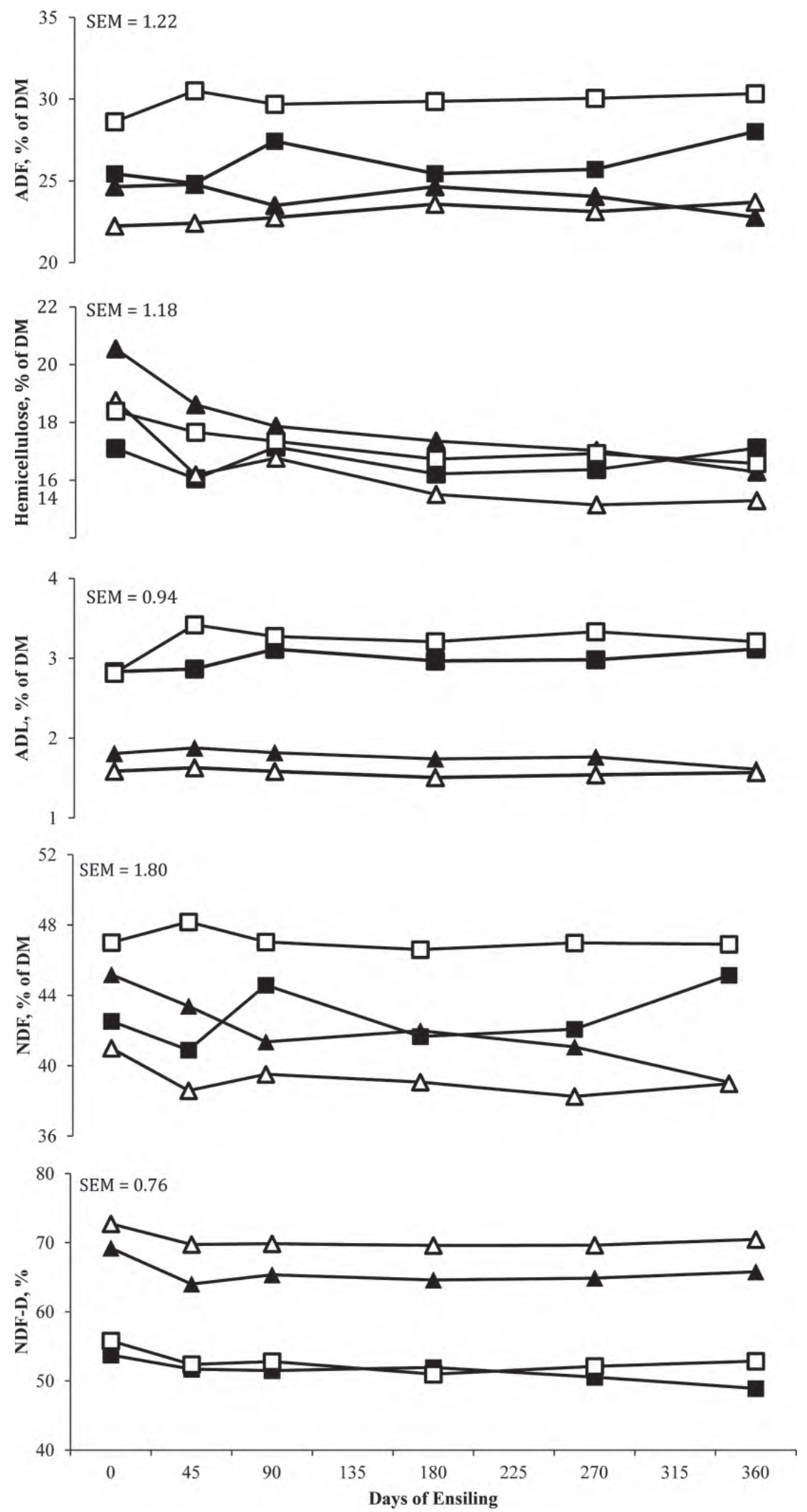

Figure 3. The concentrations of ADF (\% of DM), hemicellulose (\% of DM), ADL (\% of DM), NDF (\% of DM), and NDF digestibility (NDF-D; \% NDF) of forages. $\square=32 \%$ DM normal hybrid; $\Delta=32 \%$ DM brown midrib hybrid; $\mathbf{\square}=41 \%$ DM normal hybrid; $\boldsymbol{\Delta}=41 \%$ DM brown midrib hybrid. 

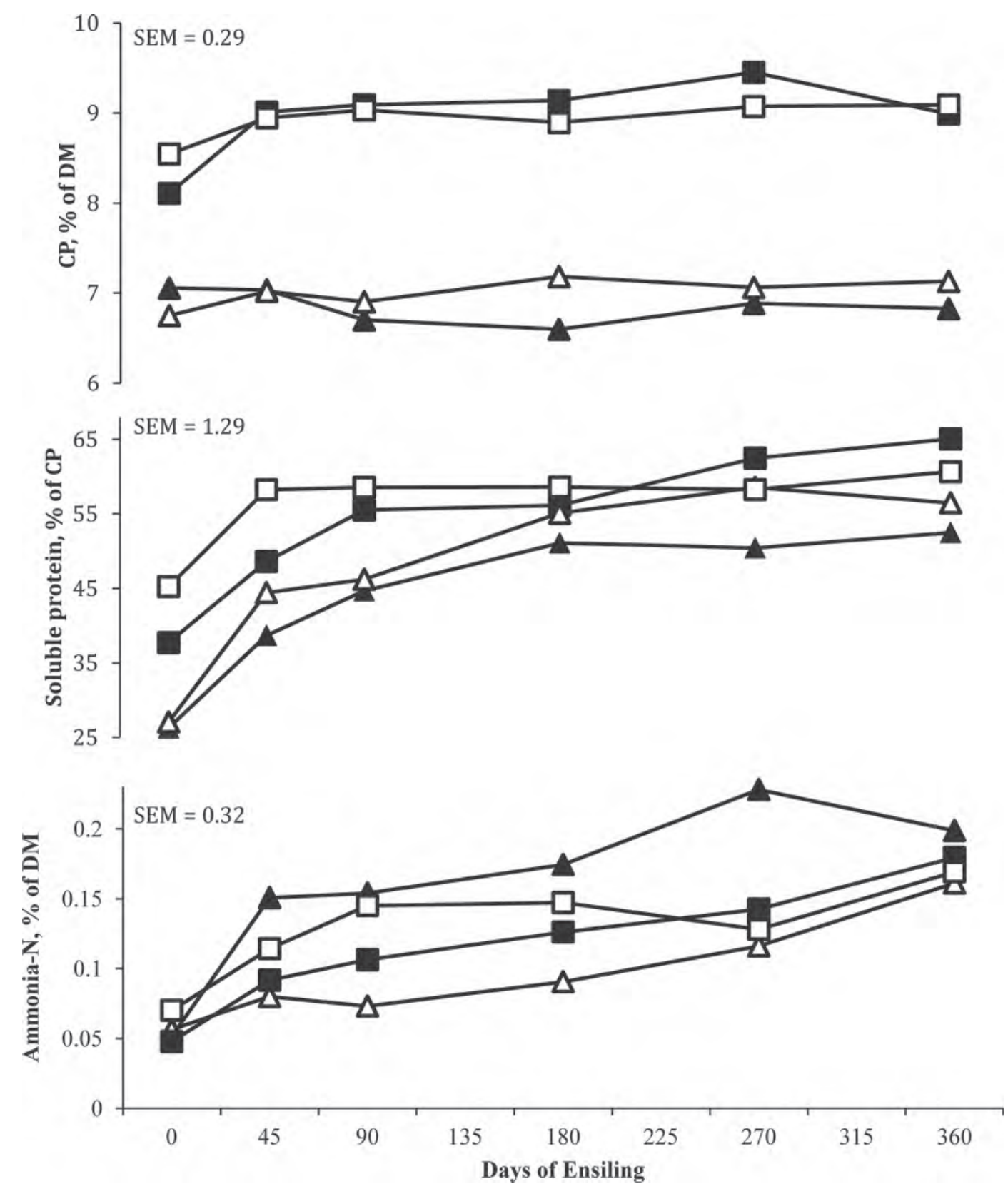

Figure 4. The concentrations of CP (\% of DM), soluble protein ( $\%$ of $\mathrm{CP}$ ), and ammonia-N (\% of DM) contents of forages. $\square=32 \%$ DM normal hybrid; $\Delta=32 \%$ DM brown midrib hybrid; $\boldsymbol{\square}=41 \% \mathrm{DM}$ normal hybrid; $\boldsymbol{\Delta}=41 \% \mathrm{DM}$ brown midrib hybrid.

for $32 \%$ DM NORM, which remained constant through d 360. The findings for 32\% DM NORM is probably best explained by the fact that immature corn with low starch content is lower in concentration of prolamin than is mature corn. In the study by Benton et al. (2005), in situ DM disappearance was substantially greater in $30 \%$ compared with $24 \%$ moisture HMC at harvest and also increased to a greater extent with time in the silo for the former. Although no reason for the increase was given in their report, greater DM disap- pearance for $30 \%$ moisture HMC was probably due to it being less mature and having lower concentrations of prolamin. Soderlund and Owens (2006) reviewed data from HMC silage and corn silage from the state of New York that were processed at the Dairy One forage laboratory (Ithaca, NY). The data showed that for HMC, SP steadily increased and peaked in August or September in the year following harvest, but for corn silage, SP remained relatively constant after only 4 to 5 mo after harvest. Based on this data, they suggested 
that if starch availability increases with protein solubility, corn silage would be a more consistent feed than HMC after a short period of storage. However, in our study, starch-D did not reach a numerical high until $270 \mathrm{~d}$ for $41 \%$ BMR and NORM and $32 \%$ DM BMR. Our data and those of others suggest that the increases in starch-D with length of storage will vary based on type of hybrid and maturity (DM) at harvest. From a practical standpoint it also suggests that producers should ensile mature corn silage for longer periods of time before feeding, whereas immature corn silage could be fed after only a few months of storage and still be highly digestible. A difficult finding to explain in our study was that starch-D in $41 \%$ DM BMR increased to a lesser extent with length of storage $(66 \%$ at $\mathrm{d} 0$ to a maximum of $76 \%$ at $270 \mathrm{~d}$ ) compared with $41 \% \mathrm{DM}$
NORM $(68 \%$ at d 0 to a maximum of $85 \%$ at d 270 and 360). A possible explanation for this is that the BMR silage line originally came from parents with high prolamin content (although we did not analyze for this component in our study), which was exacerbated with increased maturity at harvest. This finding, combined with the decrease in NDF-D with maturity, emphasizes the fact that BMR corn silage should not be allowed to become overly mature before harvest.

Increases in starch-D with prolonged length of storage may be one reason why a decrease in production sometimes occurs when cows are switched from old silage (high starch-D) to freshly ensiled corn silage (low starch-D). Furthermore, the observed increase in the potential of highly digestible starch in well-fermented silage may partly explain the increased incidence of
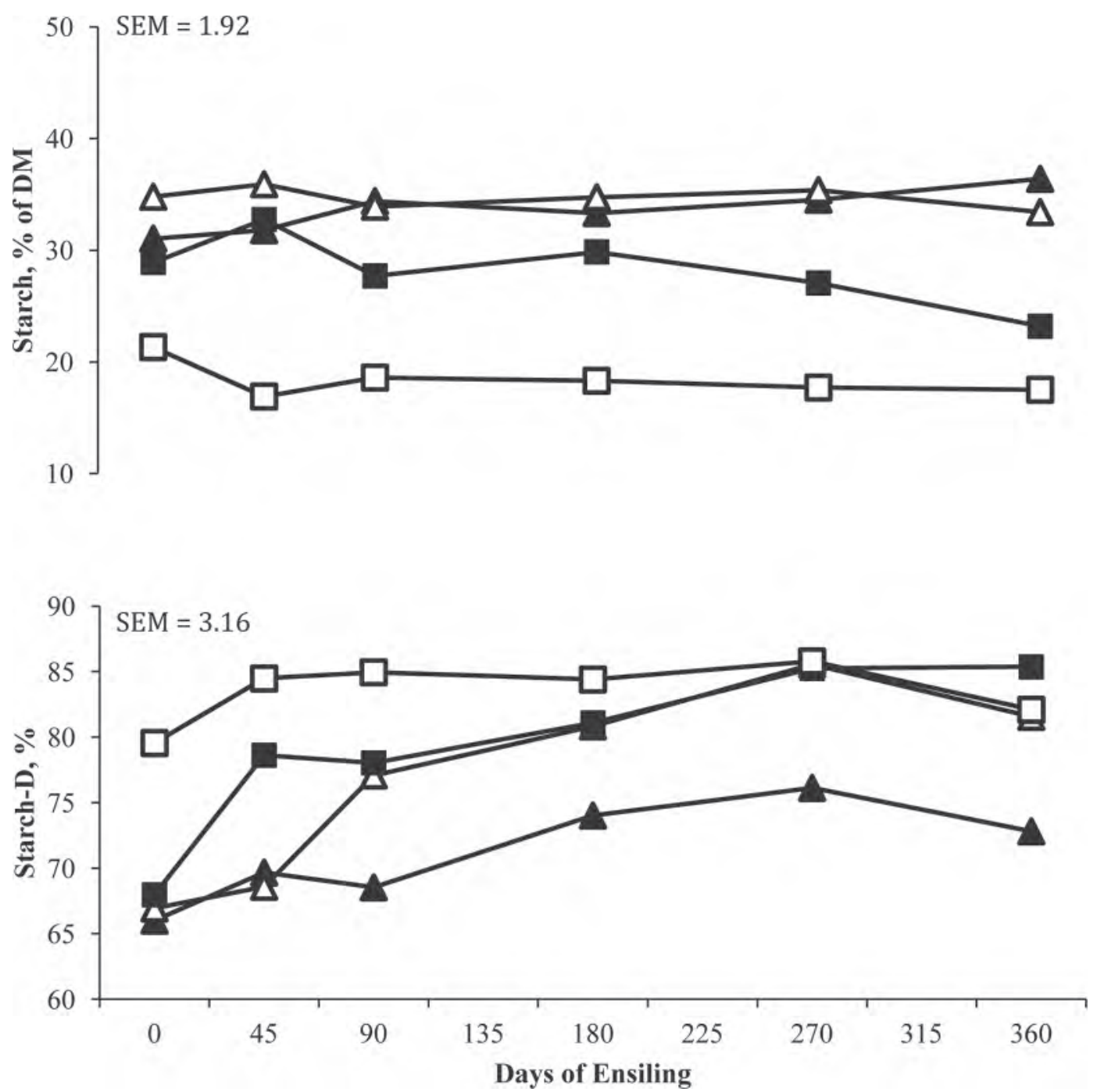

Figure 5. The concentration (\% of DM) and 7-h in vitro digestibility (starch-D; \% starch) of starch in forages. $\square=32 \%$ DM normal hybrid; $\Delta=32 \%$ DM brown midrib hybrid; $\boldsymbol{\square}=41 \%$ DM normal hybrid; $\boldsymbol{\Delta}=41 \%$ DM brown midrib hybrid. 

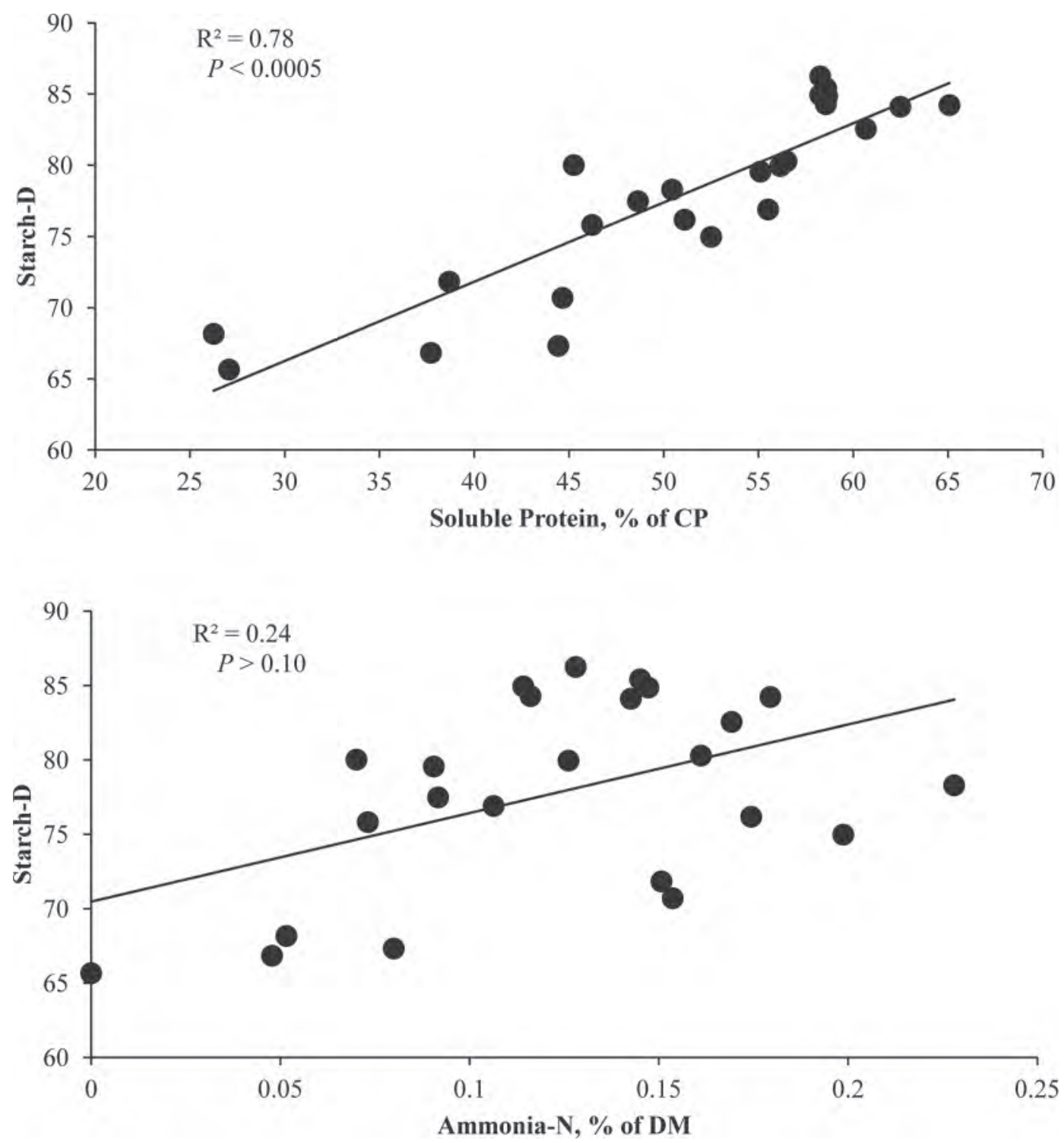

Figure 6. Correlations between soluble protein (\% of CP) and ammonia-N (\% of DM) and in vitro 7-h starch digestibility (starch-D).

acidosis that is frequently reported when animals are fed silages that have been fermented for long periods of time. Figure 6 shows simple correlations between soluble protein (\% of $\mathrm{CP}$ ) and $\mathrm{NH}_{3}-\mathrm{N}(\%$ of $\mathrm{DM})$ with in vitro starch-D. The significant correlation between SP and starch-D further strengthens the suggestion from Hoffman et al. (2011) that proteolysis is probably the reason for increased starch-D in corn-based silages. In contrast, $\mathrm{NH}_{3}-\mathrm{N}$ was not significantly correlated with in vitro starch-D, which is not surprising, as deamination is a separate process from proteolysis. In addition to showing that maturity at harvest affected in situ DM digestion of HMC (most of which was most likely starch), Benton et al. (2005) also reported that in situ DM disappearance was also improved when water was added to dry corn to raise the moisture to 28 and $35 \%$. We suspect that this treatment may have increased metabolic water for continued metabolism by lactic acid bacteria, which would explain their findings.

We evaluated only 2 of the many corn hybrids that are commercially available and, thus, more research is needed to determine how other hybrids respond to prolonged length of storage. In addition, our silages were stored at about $23^{\circ} \mathrm{C}$ in laboratory silos. Both higher and lower storage temperatures may affect the processes that occur during ensiling and storage. For example, Kim and Adesogan (2006) compared the fermentation of corn silage stored at 20 and $40^{\circ} \mathrm{C}$ and reported high concentrations of ammonia- $\mathrm{N}$ in silage stored at the higher temperature. Weinberg et al. (2001) reported 
similar findings with corn but not wheat silage. On farm, some large silos can retain significant amounts of heat in the core of the silo because of its insulated nature. A temperature logger buried in a large bunker silo at silo filling in Wisconsin showed that the core temperature of the silage mass remained between 32 and $34^{\circ} \mathrm{C}$ for more than $90 \mathrm{~d}$ until the logger was recovered at feedout (L. Kung Jr., unpublished data). In contrast, small silos (e.g., bag silos, small bunks, and uprights) may be frozen throughout in extreme weather and it is unknown if a lag in the observed increase in $\mathrm{SP}$ and starch-D would occur if silage was frozen for several months.

Although there has been considerable interest in storing corn silage and HMC for longer periods of time to improve starch digestibility, the cost:benefit ratio of this practice has not been well studied. Prolonged storage may require more inventory space and better silo management. Furthermore, DM losses are known to constantly increase during storage (Buckmaster et al., 1989; Herrmann et al., 2011) and must be accounted for in any decision to prolong the storage of silage before feeding.

\section{CONCLUSIONS}

The NDF-D of the BMR hybrid used in this study was greater than that of the NORM hybrid. To its advantage, NDF-D in the NORM hybrid was less affected by harvest at a higher DM than was the BMR hybrid. The NDF-D of both hybrids changed little between 45 and $360 \mathrm{~d}$ of ensiling. In contrast, soluble protein and ammonia- $\mathrm{N}$ concentrations increased throughout the year of storage. The increase in the former was highly correlated with an increase in starch-D with prolonged storage, suggesting that proteolysis may have been the reason for its improvement. Collectively, these data support that corn silages should be regularly monitored throughout the year and appropriate changes to ration formulations should be made to account for these changes in nutritive value. Although prolonged storage appears beneficial for corn silage in terms of increased starch-D, the impact of the increase in SP and the extent of changes in the AA content with time require further studies.

\section{ACKNOWLEDGMENTS}

This study was partially funded by Dow AgroSciences LLC (Indianapolis, IN). The authors thank Wenping $\mathrm{Hu}$ and Mateus Santos of the University of Delaware (Newark) for their help with conducting this research.
We also thank the staff of the University of Delaware Farm for management of the corn silage.

\section{REFERENCES}

Benton, J. R., T. Klopfenstein, and G. E. Erickson. 2005. Effects of corn moisture and length of ensiling on dry matter digestibility and rumen degradable protein. Nebraska Beef Cattle Reports: 31-33. Univ. Nebraska, Lincoln.

Bergen, W. G., E. H. Cash, and H. E. Henderson. 1974. Changes in nitrogenous compounds of the whole corn plant during ensiling and subsequent effects on dry matter intake by sheep. J. Anim. Sci. 39:629-637.

Buckmaster, D. R., C. A. Rotz, and R. E. Muck. 1989. A comprehensive model of forage changes in the silo. Trans. ASAE 32:11431152 .

Cherney, D. J. R., J. H. Cherney, and W. J. Cox. 2007. Forage quality differences of corn hybrids as influenced by ensiling. Forage and Grazinglands. 10.1094/FG-2007-0918-01-RS.

Ferreira, G., and D. R. Mertens. 2006. Effect of corn silage maturity and mechanical processing on nutrient digestibility by lactating dairy cows of different lactation stages. J. Dairy Sci. 89(Suppl. 1):192. (Abstr.)

Goering, H. K., and P. J. Van Soest. 1970. Forage Fiber Analyses. (Apparatus, Reagents, Procedures and Some Applications). Agric. Handbook. No 379. United States Department of Agriculture-Agricultural Research Service (USDA-ARS), Washington, DC.

Grum, D. E., W. L. Shockey, and W. P. Weiss. 1991. Electrophoretic examination of alfalfa silage proteins. J. Dairy Sci. 74:146-154.

Guo, X., H. Zhou, Z. Yu, and Y. Zhang. 2007. Changes in the distribution of nitrogen and plant enzymatic activity during ensilage of Lucerne treated with different additives. Grass Forage Sci. $62: 35-43$.

Hall, M. B. 2009. Analysis of starch, including maltooligosaccharides, in animal feeds: A comparison of methods and a recommended method for AOAC collaborative study. J. AOAC Int. 92:42-49.

Hallada, C. M., D. A. Sapienza, and D. Taysom. 2008. Effect of length of time ensiled on dry matter, starch and fiber digestibility in whole plant corn silage. J. Dairy Sci. 91(E-Suppl. 1):30. (Abstr.)

Heron, S. J. E., R. A. Edwards, and P. McDonald. 1986. Changes in the nitrogenous components of gamma irradiated and inoculated ensiled ryegrass. J. Sci. Food Agric. 37:979-985.

Heron, S. J. E., R. A. Edwards, and P. Phillips. 1989. Effect of pH on the activity of ryegrass Lolium multiflorum proteases. J. Sci. Food Agric. 46:267-277.

Herrmann, C., M. Heiermann, and C. Idler. 2011. Effects of ensiling, silage additives and storage period on methane formation of biogas crops. Bioresour. Technol. 102:5153-5161.

Hoffman, P. C., N. M. Esser, R. D. Shaver, W. Coblentz, M. P. Scott, A. L. Bodnar, R. Schmidt, and B. Charley. 2011. Influence of ensiling time and inoculation on alteration of the starch-protein matrix in high-moisture corn. J. Dairy Sci. 94:2465-2474.

Hu, W., R. J. Schmidt, E. E. McDonell, C. M. Klingerman, and L. Kung Jr.. 2009. The effect of Lactobacillus buchneri 40788 or Lactobacillus plantarum MTD-1 on the fermentation and aerobic stability of corn silages ensiled at two dry matter contents. J. Dairy Sci. 92:3907-3914.

Jones, B. A., R. D. Hatfield, and R. E. Muck. 1995. Characterization of proteolysis in alfalfa and red clover. Crop Sci. 35:537-541.

Jung, H. G., and D. A. Deetz. 1993. Cell wall lignification and degradability. Pages 315-346 in Forage Cell Wall Structure and Digestibility. H. G. Jung, D. R. Buxton, R. D. Hatfield, and J. Ralph, ed. Am. Soc. Agron. (ASA), Crop Sci. Soc. Am. (CSSA), and Soil Sci. Soc. Am. (SSSA), Madison, WI.

Kim, S. C., and A. T. Adesogan. 2006. Influence of ensiling temperature, simulated rainfall, and delayed sealing on fermentation characteristics and aerobic stability of corn silage. J. Dairy Sci. 89:3122-3132. 
Kleinschmit, D. H., and L. Kung Jr.. 2006. The effects of Lactobacillus buchneri 40788 and Pediococcus pentosaceus R1094 on the fermentation of corn silage during various stages of ensiling. J. Dairy Sci. 89:3999-4004.

Krishnamoorthy, U., T. V. Muscato, C. J. Sniffen, and P. J. Van Soest. 1982. Borate-phosphate procedure as detailed in nitrogen fractions in selected feedstuffs. J. Dairy Sci. 65:217-225.

Kunji, E. R. S., I. Mierau, A. Hagting, B. Poolman, and W. N. Konings. 1996. The proteolytic systems of lactic acid bacteria. Antonie van Leeuwenhoek 70:187-221.

Lewis, A. L., W. J. Cox, and J. H. Cherney. 2004. Hybrid, maturity, and cutting height interactions on corn forage, yield and quality. Agron. J. 96:267-274.

Lindgren, S. E., L. T. Axelsson, and R. F. McFeeters. 1990. Anaerobic L-lactate degradation by Lactobacillus plantarum. FEMS Microbiol. Lett. 66:209-213.

Morrison, I. M. 1979. Changes in the cell wall components of laboratory silages and the effect of various additives on these changes. J. Agric. Sci. 93:581-586.

Newbold, J. R., E. A. Lewis, L. Lavrijssen, H. J. Brand, H. Vedder, and J. Bakker. 2006. Effect of storage time on ruminal starch degradability in corn silage. J. Dairy Sci. 89(Suppl. 1):190. (Abstr.)

Ohshima, M., and P. McDonald. 1978. A review of the changes of in nitrogenous compounds in herbage during ensiling. J. Sci. Food Agric. 29:497-505.

Pahlow, G., R. E. Muck, F. Driehuis, S. J. W. H. Oude Elferink, and S. F. Spoelstra. 2003. Microbiology of ensiling. Pages 31-93 in Silage Science and Technology. D. R. Buxton, R. E. Muck, and J. H. Harrison, ed. American Society of Agronomy, Madison, WI.
Papadopoulos, Y. A., and B. D. McKersie. 1983. A comparison of protein degradation during wilting and ensiling of six forage species. Can. J. Plant Sci. 63:903-912.

Sanderson, M. A. 1993. Aerobic stability and in vitro fiber digestibility of microbially inoculated corn and sorghum silage. J. Anim. Sci. 71:505-514.

Schmidt, R. J., and L. Kung Jr. 2010. The effects of Lactobacillus buchneri with or without a homolactic bacterium on the fermentation and aerobic stability of corn silages made at different locations. J. Dairy Sci. 93:1616-1624.

Soderlund, S., and F. Owens. 2006. Corn hybrid by processing method considerations. Pages 62-72 in Proc. Oklahoma State University Cattle Grain Processing Symposium. University of Oklahoma, Stillwater.

Tilley, J. M. A., and R. A. Terry. 1963. A two-stage technique for the in vitro digestion of forage crops. J. Br. Grassl. Soc. 18:104-111.

Van Soest, P. J., J. B. Robertson, and B. A. Lewis. 1991. Methods for dietary fiber, neutral detergent fiber, and nonstarch polysaccharides in relation to animal nutrition. J. Dairy Sci. 74:3583-3597.

Weatherburn, M. W. 1967. Phenol-hypochlorite reaction for determination of ammonia. Anal. Chem. 39:971-974.

Weinberg, Z. G., G. Szakacs, G. Ashbell, and Y. Hen. 2001. The effect of temperature on the ensiling process of corn and wheat. J. Appl. Microbiol. 90:561-566.

Yan, J., Y. Gao, W. Wang, and S. Mu. 2009. Variation law of wholeplant corn silage nutritional quality under different storage periods. J. Northwest A. F. Univ. (Nat. Sci. Ed.) 37:75-80. 